\title{
Is the Chief Justice a Tax Lawyer?
}

Stephanie Hoffer \& Christopher J. Walker*

INTRODUCTION 33

I. STATUTORY INTERPRETATION: AN EMBRACE OF TAX LAW'S SUBSTANCE-OVER-FORM DOCTRINE? 35

II. ADMINISTRATIVE LAW: A NEW MAJOR QUESTIONS DOCTRINE OR TAX EXCEPTIONALISM? 39 CONCLUSION

\section{INTRODUCTION}

Last Term, in King v. Burwell, the Supreme Court upheld a Treasury regulation interpreting the Affordable Care Act to allow for tax subsidies in healthcare exchanges established by the Federal Government. ${ }^{1}$ The statute, I.R.C. $\S 36 \mathrm{~B}$ (Section 36B), grants premium tax credits to certain taxpayers who are "enrolled in [insurance plans] through an Exchange established by the State under section 1311." To ensure all qualifying taxpayers receive the tax credits regardless of whether their State has established its own exchange, the Treasury Department promulgated a regulation interpreting "an Exchange established by the State" to include any "State Exchange, regional Exchange, subsidiary Exchange, and Federally-facilitated Exchange." " The challengers to the regulation argued that the agency's interpretation was contrary to the plain text of the statute.

In a 6-3 decision authored by Chief Justice Roberts, the Court did not find the statutory language unambiguous. ${ }^{4}$ Nor, however, did it accord deference

* Professor of Law and Assistant Professor of Law, respectively, Michael E. Moritz College of Law, The Ohio State University.

1. King v. Burwell, 135 S. Ct. 2480, 2496 (2015).

2. I.R.C. $\$ 36 \mathrm{~B}(\mathrm{c})(2)(\mathrm{A})(\mathrm{i})(2012)$.

3. Health Insurance Premium Tax Credit, 77 Fed. Reg. 30,377-01, 30,378 (May 23, 2012) (codified at 26 C.F.R. pts. $1 \& 602$ ) (citing 45 C.F.R. $\$ 155.20$ ) (noting that "[c]ommentators disagreed on whether the language in section $36 \mathrm{~B}(\mathrm{~b})(2)(\mathrm{A})$ limits the availability of the premium tax credit only to taxpayers who enroll in qualified health plans on State Exchanges," but concluding that it did not so limit because the broader interpretation "is consistent with the language, purpose, and structure of section 36B and the Affordable Care Act as a whole").

4. King, 135 S. Ct. at 2492. 
to the agency's interpretation of the statutory ambiguity. ${ }^{5}$ Instead, the Court interpreted the statute de novo and concluded that "the context and structure of the Act compel us to depart from what would otherwise be the most natural reading of the pertinent statutory phrase" to "allow[] tax credits for insurance purchased on any Exchange created under the Act." That is because the premium tax "credits are necessary for the Federal Exchanges to function like their State Exchange counterparts, and to avoid the type of calamitous result that Congress plainly meant to avoid." "7

King v. Burwell is a crucial victory for the Obama Administration and for the future of the Affordable Care Act. It also has important implications for tax law and administration, as explored in the other terrific contributions to this Symposium. ${ }^{8}$ In this Essay, we turn to another tax-related feature of the Chief Justice's opinion for the Court: It is hard to ignore the fingerprints of a tax lawyer throughout the opinion.

This Essay focuses on two instances of a tax lawyer at work. First, in the Chief's approach to statutory interpretation one sees a tax lawyer as interpreter. As others have observed, the Chief and the Court more generally seem to be embracing a brand of contextualism that departs from the textualism that has predominated during Justice Scalia's tenure on the Court. The Chief's articulation of this interpretive approach in King, however, tracks tax law's substance-over-form doctrine. In particular, the Chief looks beyond Congress's formal, textual characterization of the statutory provision to recharacterize the provision based on strong proof of its true nature or substance. ${ }^{9}$ Indeed, this is not the first time the Chief has taken an approach similar to the substance-over-form doctrine when interpreting the Affordable Care Act. He also seemed to do so when rejecting the constitutional challenge to the statute three Terms prior. ${ }^{10}$

Second, as to King's sweeping administrative law holding that is the main subject of this Symposium, the Chief crafts a new major questions doctrine that could significantly cut back on federal agency lawmaking authority by

\footnotetext{
5. Id. at 2489 .

6. Id. at $2495-96$.

7. Id. at 2496 .

8. See Ellen Aprill, King v. Burwell and Tax Court Review of Regulations, 2015 PEPP. L. REV. 6 (2015); Andy Grewal, King v. Burwell: Where Were the Tax Professors?, 2015 PEPP. L. REV. 48 (2015); Kristin Hickman, The (Perhaps) Unintended Consequence of King v. Burwell, 2015 PEPP. L. REV. 56 (2015); Steve Johnson, The Rise and Fall of Chevron in Tax: From the Early Days to King and Beyond, 2015 PEPP. L. REV. 19 (2015); Leandra Lederman \& Joseph C. Dugan, King v. Burwell: What Does It Portend for Chevron's Domain?, 2015 PEPP. L. REV. 72 (2015). For an overview of the Symposium, see David Gamage, Foreword-King v. Burwell Symposium: Comments on the Commentaries (and on Some Elephants in the Room), 2015 PEPP. L. REV. 1 (2015).

9. King, 135 S. Ct. at 2496.

10. See Nat'1 Fed'n of Indep. Bus. v. Sebelius, 132 S. Ct. 2566, 2594 (2012).
} 
not applying Chevron deference at all to "question[s] of "deep economic and political significance."'11 Yet the Chief seems to develop this doctrine against the backdrop of tax exceptionalism - the notion that general administrative law principles do not apply to tax - and thus this development may be limited to extraordinary circumstances at the intersection of tax and administrative law.

This Symposium importantly addresses the effect of King $v$. Burwell on tax law and administration. As this Essay illustrates, however, it is also worth exploring the potential effect of tax law on the Chief's opinion. Tax exceptionalism may well limit the opinion's impact on administrative law, and tax law may better inform the Chief's (and the Court's) evolution from textualism to contextualism in statutory interpretation. The growing call to abandon the perception that tax is exempt from general principles of administrative law may well be correct. We believe it is. But that does not mean tax law cannot provide us with special insights that can be applied in other legal contexts.

\section{STATUTORY INTERPRETATION: AN EMBRACE OF TAX LAW'S SUBSTANCE-OVER-FORM DOCTRINE?}

A number of scholars have observed an emerging trend in the Court's approach to statutory interpretation: some form of purposivism is reemerging from the Court's predominantly textualist approach. As one of us has noted, "it appears that contextualism is quickly replacing Justice Scalia's textualism as the foundation for statutory interpretation."12 Richard Re has labeled this novel form of statutory interpretation "The New Holy Trinity," arguing that the Chief's opinion in King as well as a number of other opinions from the Court reveal a more purposivist approach where "legal ambiguity can spring from a mix of text, purpose, and pragmatism."13 Others have reached similar conclusions about this purposivist revival. ${ }^{14}$

11. King, 135 S. Ct. at 2489 (quoting Util. Air Regulatory Grp. v. EPA, 134 S. Ct. 2427, 2444 (2014)).

12. Christopher J. Walker, What King v. Burwell Means for Statutory Interpretation, YALE J. ON REG.: NOTICE \& COMMENT (June 25, 2015), http://www.yalejreg.com/blog/what-king-v-burwellmeans-for-statutory-interpretation-by-chris-walker.

13. Richard M. Re, The New Holy Trinity, 18 GREEN BAG 2D 407, 421 (2015); see id. at 413-15 (discussing King, 135 S. Ct. 2480). Professor Re's formulation invokes the famous case Holy Trinity Church v. United States, in which the Supreme Court declared that "[i]t is a familiar rule that a thing may be within the letter of the statute and yet not within the statute, because not within its spirit nor within the intention of its makers." 143 U.S. 457, 459 (1892).

14. See, e.g., Michael Dorf, Why Can't Consequences Create Ambiguity?, DoRf ON LAW (June 4 2014), http://www.dorfonlaw.org/2014/06/why-cant-consequences-create-ambiguity.html; Rick Hasen, King v. Burwell: The Return of "Purpose" in Statutory Interpretation, ELECTION LAW BLOG 
For tax lawyers, the Chief's move in King v. Burwell from text or formality to context or substance is not an unfamiliar one. The divergence of written words from the reality of life is an ever-present feature of tax law. By focusing on the intended effect and actual operation of Section 36B, rather than its outward trappings, the Chief tapped into a longstanding tradition of tax jurisprudence: the substance-over-form doctrine. ${ }^{15}$

The substance-over-form doctrine requires courts to "look beyond the taxpayers' characterization" of a transaction to determine the transaction's economic effect. ${ }^{16}$ The "analysis is inherently factual," and it requires a court to consider evidence on both the intended purpose and the economic effect of a taxpayer's actions. ${ }^{17}$ When the substance of a transaction differs from its form in a way that provides the taxpayer with an undue benefit, a court may recharacterize the transaction in accordance with its true nature. ${ }^{18} \mathrm{~A}$ taxpayer, however, is usually stuck with the characterization that she chooses; she may deviate only in limited circumstances. ${ }^{19}$ In some jurisdictions, a court may recharacterize a transaction at the taxpayer's request if she produces "strong proof" to support the new characterization. ${ }^{20}$ In other jurisdictions, the taxpayer must produce proof that would be admissible either to support reformation of the agreement underlying the transaction or to show unenforceability arising from contract defenses such as mistake, misrepresentation, or duress. ${ }^{21}$

(June 25, 2015), http://electionlawblog.org/?p=73760; Marty Lederman, Textualism? Purposivism? The Chief Justice Comes Down on the Side of Interpretive Pragmatism, SLATE (June 25, 2015), http://www.slate.com/articles/news_and_politics/the_breakfast_table/features/2015/scotus_roundup/ supreme_court_2015_john_roberts_ruling_in_king_v_burwell.html.

15. The doctrine first appeared in Gregory v. Helvering, in which the Supreme Court disregarded the form of a transaction that was "masquerading as a corporate reorganization" when it was something else entirely. 293 U.S. 465, 470 (1935). In disregarding the taxpayer's characterization of the transaction, the court refused "to exalt artifice above reality." Id. A later court of appeals noted that the doctrine is "elementary in the law of taxation." Shultz v. Comm'r, 294 F.2d 52, 56 (9th Cir. 1961).

16. True v. United States, 190 F.3d 1165, 1174 (10th Cir. 1999) ("This fundamental tax principle" prefers the "true nature of [the] transaction" over "mere formalisms.").

17. Id. at $1177-78$.

18. See Unites States v. Ingalls, 399 F.2d 143 (5th Cir. 1968) (recharacterizing employer's purchase of employee's contract as blanket forgiveness of employee's debt to employer).

19. See Shultz, 294 F.2d at 56 ((noting that when taxpayers, rather than the Commissioner, seek to deviate from formalities of the transaction, courts rely "heavily on the formal means which the parties used").

20. See Muskat v. United States, 554 F.3d 183, 188 (1st Cir. 2009) (requiring strong proof that intended allocation of contract price differed from allocation specified by document); Kreider $v$. Comm'r, 762 F.2d 580, 586-87 (7th Cir. 1985) (requiring strong proof that payment was additional consideration for stock "rather than what [the agreement] says it is").

21. See Comm'r v. Danielson, 378 F.2d 771, 775 (3d Cir. 1967) (holding that "a party can challenge the tax consequences of his agreement as construed by the Commissioner only by adducing proof which in an action between the parties to the agreement would be admissible to alter that construction or to show its unenforceability because of mistake, undue influence, fraud, duress, etc."). 
In King v. Burwell, the Chief has unleashed his inner tax lawyer with a brand of contextualism that seems to take cues from the substance-over-form doctrine. Interpreting the statutory language at issue-which, at first blush, appears to deny a tax credit (or grants a credit of $\$ 0$ ) to taxpayers who purchased insurance on an exchange other than one "established by the State"-the Court waded into a discussion of purpose, effect, and congressional intent. ${ }^{22}$ Or, from the perspective of a tax lawyer, the Chief demonstrated a preference for legislative substance over form.

In contrast to the constitutional challenge to the Affordable Care Act addressed in National Federation of Independent Businesses v. Sebelius $(N F I B),{ }^{23}$ discussed below, where the Federal Government sought the Court's affirmation of its chosen form, the Government in King v. Burwell called for the Court to either read into, or essentially disregard, the language of the statute. ${ }^{24}$ In tax law, when a party to a transaction seeks to disavow the form of that transaction, the party must either provide strong proof to support the alternative characterization, or demonstrate that the agreement underlying the chosen form would be alterable or voidable under contract law. ${ }^{25}$

The Chief's opinion in King v. Burwell, albeit unintentionally, provides support for satisfaction of both the strong proof and the voidable contract standards applicable to a disavowal of form. It is apparent that the Court's primary concern was substance. Quoting a prior case, the Chief wrote that interpreting a section of the Internal Revenue Code in the context of an entire statutory scheme may bring clarity "because only one of the permissible meanings produces a substantive effect that is compatible with the rest of the law."26 Put differently,

A fair reading of legislation demands a fair understanding of the legislative plan.

Congress passed the Affordable Care Act to improve health insurance markets, not to destroy them. If at all possible, we must interpret the Act in a way that is consistent with the former, and avoids the latter. Section $36 \mathrm{~B}$ can fairly be read consistent with what

22. King v. Burwell, 135 S. Ct. 2480, 2488 (2015); I.R.C. § 36B(b)-(c) (2012).

23. 132 S. Ct. 2566 (2012).

24. As Justice Scalia noted in his dissent in King, "Words no longer have meaning if an Exchange that is not established by a State is "established by the State." King, 135 S. Ct. at 2497 (Scalia, J., dissenting).

25. See supra notes $19-21$ and accompanying text.

26. King, 135 S. Ct. at 2492 (emphasis added) (quoting United Sav. Ass'n of Tex. v. Timbers of Inwood Forest Assocs., Ltd., 484 U.S. 365, 371 (1988)) 
we see as Congress's plan, and that is the reading we adopt. ${ }^{27}$

Having chosen to elevate substance over plain meaning, the Chief reviewed the facts and relied on "strong proof" that the substantive meaning of the law is something different than the words with which it is recorded. ${ }^{28}$ This proof was not limited to evidence of congressional purpose provided by a fair reading of the statute as a whole. The Chief also relied on evidence from the experiences of various states that had implemented laws similar to the one at issue ${ }^{29}$ and on reports from multiple experts regarding "the type of calamitous result that Congress plainly meant to avoid." ${ }^{30}$

The Chief's opinion also might support an application of the voidable contract standard for disavowal of form. Its discussion of the legislative bargaining process contains many of the elements needed to build a case for reformation on the basis of mistake or, if one stretches, unconscionability ${ }^{31}$ The Chief chides Congress for its "inartful drafting" and observes that much of the process was conducted "behind closed doors" with "limited opportunities for debate and amendment" and no opportunity for the usual sixty-vote filibuster. ${ }^{32}$ Taken in the aggregate, these observations highlight the infirmity of the statutory drafting in juxtaposition to the seeming clarity of the law's intended effect, just as similar showings in the transactional context would highlight the infirmity of the claimed form of a transaction that deviates from its economic substance.

Accordingly, the Chief concludes that although the argument for the statute's plain meaning is "strong," it is "implausible" that Congress intended the dramatic result that a plain interpretation would render. ${ }^{33}$ In other words, for our Chief Justice as a tax lawyer in King $v$. Burwell, it was the effect of Section $36 \mathrm{~B}$-its substance - that mattered more than its textual form.

27. Id. at 2496.

28. See Kreider v. Comm'r, 762 F.2d at 586-87 (requiring "strong proof" of taxpayer's claim that the substance of a transaction was different from the form claimed by the taxpayer).

29. See King, 135 S. Ct. at 2486 (describing the experiences of Massachusetts, New York, and Washington).

30. Id. at 2496; see id. at 2493 (considering expert opinions)

31. Traditionally, reformation on the basis of mistake occurs "when the parties, having reached an agreement and having then attempted to reduce it to writing, fail to express it correctly in the writing." RESTATEMENT (SECOND) OF CONTRACTS $\S 155 \mathrm{cmt}$. a. A contract may be reformed or avoided on the basis of unconscionability when the substantive result is so unfair as to "shock the conscience" and when the bargaining process suffered from a procedural flaw such as unfairness in negotiation of the contract, oppression due to unequal bargaining power, or unfair surprise resulting from hidden terms. See Ferguson v. Countrywide Credit Inds., 298 F.3d 778, 783-784 (9th Cir. 2002).

32. King, 135 S. Ct. at 2492-93.

33. Compare id. at 2495 ("Petitioners' arguments about the plain meaning of Section 36B are strong."), with id. at 2494 ("It is implausible that Congress meant the Act to operate in this manner."). 
We would be remiss if we failed to mention that the Chief's focus on substance in King was not a flash in the pan. The Chief's prior opinion in $N F I B$ also suggests that the Chief's spirit animal is, indeed, a tax lawyer. Again interpreting the Affordable Care Act, he wrote that "[t]he most straightforward reading" of the Act's individual mandate "commands individuals to purchase insurance," but, substantively, the mandate is a tax on the failure to do so. ${ }^{34}$ To reach this conclusion, the Chief focused on the realworld effect of the law, just as a court would do if it were applying the substance-over-form doctrine in a transactional context. ${ }^{35}$ He observed that the law "looks like a tax" even though Congress called it a "shared responsibility payment." ${ }^{36}$ He noted that the required payment is made to the Internal Revenue Service (IRS) by "taxpayers" and that "its amount is determined by such familiar factors as taxable income, number of dependents, and joint filing status." ${ }^{37}$ Like any jurist in a tax case confronted by a mismatch between form and substance, the Chief concluded that the validity of the individual mandate was "not controlled by Congress's choice of label.".38

Elevating substance over form, the opinions in King and NFIB suggest that the country's chief jurist would be just as adept on the Tax Court as on the Supreme Court. More importantly, jurists such as the Chief who seem interested in replacing textualism with contextualism in statutory interpretation would be wise to look more closely at tax law, as tax lawyers have long struggled in the transactional context with the tension between substance and form.

\section{ADMINISTRATIVE LAW: A NEW MAJOR QUESTIONS DOCTRINE OR TAX EXCEPTIONALISM?}

Tax also seems to pervade the Chief's approach to administrative law in King $v$. Burwell. That the Government prevailed in King may not have been too surprising, despite the fact that many court watchers were unsure after argument which way the Court would rule. The way the Court reached its decision, however, was surprising - at least to administrative law practitioners and scholars. ${ }^{39}$

\footnotetext{
34. Nat'l Fed'n of Indep. Bus. v. Sebelius, 132 S. Ct. 2566, 2593 (2012).

35. See id. at 2594.

36. Id. at 2594-95.

37. Id. at 2594 .

38. Id. at 2595 .

39. This Part builds on and borrows from a post one of us authored the day King v. Burwell was decided. See Christopher J. Walker, What King v. Burwell Means for Administrative Law, YALE J. ON REG.: NOTICE \& COMMENT (June 25, 2015), http://www.yalejreg.com/blog/what-king-v-burwell-
} 
After all, the Court was reviewing an agency's interpretation of a statute that Congress has charged the agency to administer. ${ }^{40}$ Under the Chevron twostep approach, the Court defers to an agency's interpretation of a statute it administers if, at Step One, the court finds "the statute is silent or ambiguous" and then, at Step Two, determines that the agency's reading is a "permissible construction of the statute." ${ }^{\text {41 }}$ This is a generous standard for agencies. The Court "need not conclude that the agency construction was the only one it permissibly could have adopted ... or even the reading the court would have reached if the question initially had arisen in a judicial proceeding." 42

Under Chevron deference, to uphold the regulation in King, one may have expected the Court to find the statutory provision ambiguous at Step One and then defer to the agency's interpretation as reasonable at Step Two. Or, if the Court truly believed the statute was unambiguous in the Government's favor (or, perhaps the more cynical view, that it wanted to foreclose a subsequent presidential administration from reinterpreting the statute via regulation to prohibit tax subsidies in exchanges established by the Federal Government), the Court could have just ruled that the statute is unambiguous at Chevron Step One, after applying the traditional tools of statutory interpretation.

Instead, writing for the six-Justice majority, the Chief broke new ground in administrative law, ruling that Chevron deference does not apply to questions such as this one that are of "deep economic and political significance." ${ }^{33}$ This new major questions doctrine is crisply articulated in two paragraphs from the Chief's opinion:

When analyzing an agency's interpretation of a statute, we often apply the two-step framework announced in Chevron, 467 U.S. 837. Under that framework, we ask whether the statute is ambiguous and, if so, whether the agency's interpretation is reasonable. Id. at 842 43. This approach "is premised on the theory that a statute's ambiguity constitutes an implicit delegation from Congress to the agency to fill in the statutory gaps." FDA v. Brown \& Williamson Tobacco Corp., 529 U.S. 120, 159 (2000). "In extraordinary cases,

means-for-administrative-law-by-chris-walker.

40. See I.R.C. $\S 36 \mathrm{~B}(\mathrm{~g})$ (2012) (providing that " $[\mathrm{t}]$ he Secretary [of the Treasury] shall prescribe such regulations as may be necessary to carry out the provisions of this section").

41. Chevron, U.S.A., Inc. v. Natural Res. Def. Council, Inc., 467 U.S. 837, 843 (1984).

42. Id. at 843 n.11.

43. King v. Burwell, 135 S. Ct. 2480, 2489 (2015) (internal quotation marks omitted). To be sure, Justice Kennedy perhaps foreshadowed such a conclusion at oral argument when he noted in discussing Chevron deference that "it seems to me a drastic step for us to say that the Department of Internal Revenue and its director can make this call one way or the other when there are, what, billions of dollars of subsidies involved here." Transcript of Oral Argument at 74, King v. Burwell, 135 S. Ct. 2480 (2015) (No. 14-114). 
however, there may be reason to hesitate before concluding that Congress has intended such an implicit delegation." Ibid.

This is one of those cases. The tax credits are among the Act's key reforms, involving billions of dollars in spending each year and affecting the price of health insurance for millions of people. Whether those credits are available on Federal Exchanges is thus a question of deep "economic and political significance" that is central to this statutory scheme; had Congress wished to assign that question to an agency, it surely would have done so expressly. Util. Air Regulatory Grp. v. EPA, 134 S. Ct. 2427, 2444 (2014) (quoting Brown \& Williamson, 529 U.S. at 160). It is especially unlikely that Congress would have delegated this decision to the IRS, which has no expertise in crafting health insurance policy of this sort. See Gonzales v. Oregon, 546 U.S. 243, 266-267 (2006). This is not a case for the IRS. ${ }^{44}$

Citing Justice O'Connor's opinion in Brown \& Williamson is often a strong signal that a court is departing from traditional administrative law principles. And, sure enough, the Chief cites Brown \& Williamson extensively as part of his effort to reassert the judiciary's primary role in interpreting statutes that raise questions of "deep economic and political significance." ${ }^{\text {"45 }}$ This new major questions doctrine is a major blow to a brightline, rule-based approach to Chevron deference. To be sure, the major questions doctrine - the presumption, as Justice Scalia artfully framed it in Whitman v. American Trucking Ass'ns, that Congress "does not . . . hide elephants in mouseholes" here seems strained and less obvious. A number of other contributions to this Symposium explore the extraordinary nature of this new doctrine, with one contributor remarking that this may be the death of Chevron, ${ }^{47}$ another explaining how this extraordinary case makes bad law, ${ }^{48}$ and a third mapping the unintended yet far-reaching consequences of this new administrative law doctrine. $^{49}$

Moreover, the Chief's case-by-case approach of looking to the particular statutory subsection for congressional intent of delegation (at least for major questions) reads a lot like his dissent in City of Arlington v. FCC. ${ }^{50}$ There, the

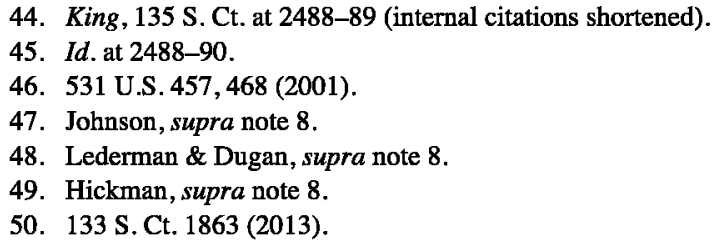


Chief argued that "[a] court should not defer to an agency until the court decides, on its own, that the agency is entitled to deference."51 The City of Arlington Court, with Justice Scalia writing, rejected this case-by-case approach in the context of agency jurisdiction questions (which are arguably another type of major questions). In particular, Justice Scalia dismissed the Chief's approach that "even when general rulemaking authority is clear, every agency rule must be subjected to a de novo judicial determination of whether the particular issue was committed to agency discretion." 52

One could say that King $v$. Burwell-while a critical win for the Obama Administration - is a judicial power grab over the Executive in the modern administrative state. Some may say this judicial intervention is long overdue in light of the staggering amount of lawmaking authority Congress has delegated to federal agencies. ${ }^{53}$ In calling for closer judicial scrutiny of agency statutory interpretations in City of Arlington, the Chief's dissent noted that, "with hundreds of federal agencies poking into every nook and cranny of daily life, [the ordinary] citizen might ... understandably question whether Presidential oversight-a critical part of the Constitutional plan -is always an effective safeguard against agency overreaching." 54 It will be interesting to see whether this new major questions doctrine is a one-off holding made under extraordinary circumstances, or whether there will be further cutting back on the scope of federal agency lawmaking authority. A number of the other contributors to this Symposium seem firmly in the camp of King $v$. Burwell constituting a sea change in administrative law. ${ }^{55}$

We are not so sure-at least not yet. There are hints in the opinion of the Chief channeling a tax lawyer, suffering from "tax myopia"56 and thus crafting an opinion that may well be good only for tax. As we have explored elsewhere, this tax exceptionalism-the perception that tax is so different from the rest of the regulatory state that general administrative law principles do not apply - has long plagued tax law. ${ }^{57}$ To be sure, the Supreme Court, the

51. Id. at 1877 (Roberts, C.J., dissenting).

52. Id. at 1874 .

53. See, e.g., Christopher J. Walker, Inside Agency Statutory Interpretation, 67 STAN. L. REV. 999, 1000-02 (2015) (documenting debate and rise of agency lawmaking).

54. City of Arlington, $133 \mathrm{~S}$. Ct. at 1879 (Roberts, C.J., dissenting).

55. See Hickman, supra note 8, at 70; Johnson, supra note 8, at 31-32; Lederman \& Dugan, supra note 8, at 80-81.

56. See Paul L. Caron, Tax Myopia, or Mamas Don't Let Your Babies Grow Up to Be Tax Lawyers, 13 VA. TAX REV.517,518-19 (1994) (arguing that "tax law too often is mistakenly viewed by lawyers, judges, and law professors as a self-contained body of law" and that "this misperception has impaired the development of tax law by shielding it from other areas of law that should inform the tax debate").

57. See Stephanie Hoffer \& Christopher J. Walker, The Death of Tax Court Exceptionalism, 99 MINN. L. REV 221 (2014); see also Kristin E. Hickman, The Need for Mead: Rejecting Tax Exceptionalism in Judicial Deference, 90 MINN. L. REV. 1537, 1541 (2006) (describing the 
D.C. Circuit, and most recently the Tax Court have all signaled the demise of tax exceptionalism, calling for tax law to be bound by the Administrative Procedure Act (APA) and general principles of administrative law. ${ }^{58}$ But tax exceptionalism persists. The Chief's opinion, for instance, shows some symptoms. This could signal that, in developing a new major questions doctrine, the Chief intended to "carve out an approach to administrative review good for tax law only"-something that would be quite ironic considering that the Chief also authored the Mayo decision that rejected tax exceptionalism in the Chevron deference context. ${ }^{59}$

The strongest evidence of such tax exceptionalism lies in the Chief's reasoning for not according any deference to the agency's interpretation. The Chief concluded that Congress did not delegate this interpretive question because it involved "billions of dollars in spending each year and affect[ed] the price of health insurance for millions of people"-deep economic and political questions. ${ }^{60}$ But he also found it "especially unlikely that Congress would have delegated this decision to the IRS, which has no expertise in crafting health insurance policy of this sort." ${ }^{\text {"61 }}$ In other words, it is the exceptional nature of the IRS in this context (in particular, its lack of expertise) that suggests the lack of congressional delegation.

Andy Grewal, another contributor to this Symposium, has argued elsewhere that the Chief misunderstood the expertise at issue:

The IRS doesn't purport to be a master of health care reform, renewable energy, or international economic policy. Rather, the IRS's expertise relates to understanding how complex tax code provisions bear on those things. This is a much more modest task and involves exploring different interpretations within statutorily

"perception of tax exceptionalism that intrudes upon much contemporary tax scholarship and jurisprudence").

58. See Mayo Found. for Med. Educ. \& Research v. United States, 562 U.S. 44, 56 (2011) (finding "no reason why ... review of tax regulations should not be guided by agency expertise pursuant to Chevron to the same extent as ... review of other regulations"); Cohen v. United States, 650 F.3d 717, 723,736 (D.C. Cir. 2011) (en banc) (holding that the judicial review provisions of the APA apply with full force to an IRS notice because "[t] he IRS is not special in this regard; no exception exists shielding it-unlike the rest of the Federal Government-from suit under the APA"); Altera Corp. \& Subsidiaries v. Comm'r, 145 T.C. No. 3 , at $* 28$ (July 27, 2015) (invalidating income tax regulations because they were not the product of "reasoned decisionmaking" as required by the APA and related administrative law precedent).

59. Cf. Mayo, 562 U.S. 44 at 55 (refusing "to carve out an approach to administrative review good for tax law only").

60. King v. Burwell, 135 S. Ct. 2480,2489 (2015).

61. Id. 


\section{defined parameters. ${ }^{62}$}

Similarly, as Leandra Lederman and Joseph Dugan explore more fully in their contribution to the Symposium, neither the Treasury nor the IRS actually developed this definition of "exchange"; instead, the Treasury regulation at issue incorporated the definition already promulgated by the Department of Health and Human Services-a federal agency with even more expertise in this subject matter. ${ }^{63}$

Moreover, Kristin Hickman, also a contributor to this Symposium, has explored empirically how the IRS engages in a substantial amount of nontax regulation - thus requiring it to try to acquire more substantive expertise in a number of subject matters. ${ }^{64}$ The amount of nontax regulation in which the IRS must engage may well have been on the Chief's mind when refusing to assume that Congress intended to delegate the premium tax credit question to the IRS. Perhaps the Chief was signaling in King that Congress should stop delegating nontax issues to the IRS.

The evidence of tax exceptionalism, however, extends beyond a few sentences about the IRS's lack of expertise in "crafting health insurance policy of this sort." 65 Perhaps one of the starkest oddities in the Chief's opinion is his repeated use of the term "IRS Rule" to describe the agency regulation under review. The Chief uses this term eight times in his opinion. ${ }^{66}$ For tax lawyers and scholars, it is quite anomalous to refer to federal tax regulations as IRS Rules when the well-established terminology is Treasury regulations. ${ }^{67}$ Under the Affordable Care Act Congress expressly delegated the regulatory authority at issue to the Secretary of the Treasury; ${ }^{68}$ the regulations, moreover, formally originated from the Treasury, in coordination with the IRS. ${ }^{69}$

62. Andy Grewal, The IRS Isn't an Expert?, YALE J. ON REG.: NOTICE \& COMMENT (June 29, 2015), http://www.yalejreg.com/blog/the-irs-isn-t-an-expert-by-andy-grewal.

63. Treas. Reg. $\$ 1.36 \mathrm{~B}-1(\mathrm{k})$ (2015) (defining "exchange" to have "the same meaning as in 45 CFR 155.20"). See generally Lederman \& Dugan, supra note 8.

64. Kristin E. Hickman, Administering the Tax System We Have, 63 DUKE L. J. 1717, 1747, 1760 61 (2014).

65. King, 135 S. Ct. at 2489.

66. See id. at $2487,2488,2494$.

67. As the IRS itself explains, "Treasury regulations (26 C.F.R.)-commonly referred to as Federal tax regulations - pick up where the Internal Revenue Code (IRC) leaves off by providing the official interpretation of the IRC by the U.S. Department of the Treasury." Tax Code, Regulations and Official Guidance, IRS (last updated Feb. 6, 2015), http://www.irs.gov/Tax-Professionals/TaxCode,-Regulations-and-Official-Guidance-26cfr.

68. I.R.C. $\& 36 \mathrm{~B}(\mathrm{~g})(2012)$ (providing that "[t]he Secretary [of the Treasury] shall prescribe such regulations as may be necessary to carry out the provisions of this section").

69. Health Insurance Premium Tax Credit, 77 Fed. Reg. 30,377-01, 30,377 (May 23, 2012) (noting that "[a]fter consideration of all the comments, the proposed regulations are adopted as amended by this Treasury decision"). 
In case there was any doubt about the Chief's exceptional use of "IRS Rule" in King, the Court appears to have never before referred to agency interpretations of the Internal Revenue Code as IRS Rules. To date, the Court has used the term "Treasury Regulation" in 374 cases, but the term "IRS Rule" appears just once, in King v. Burwell. ${ }^{70}$ The term "IRS Rule" seems to be traced to the Petitioners' briefing in this case. ${ }^{71}$ The Chief seems to have then decided to adopt their use of the term throughout his opinion for the Court.

The Chief's use of IRS Rule may be strong evidence that he is not, in fact, a tax lawyer, as no tax lawyer would call a Treasury regulation an IRS Rule. If so, the question posed by the title of this Essay may have an easy, not-sointeresting answer. But his use of the term may also reflect his tax exceptionalist orientation, in that he views IRS statutory interpretations as different from-and owed less deference than-interpretations advanced by other agencies. ${ }^{72}$ Indeed, reference to the IRS (instead of Treasury) is reminiscent of the controversy surrounding some politicians' use of IRS Code (instead of Internal Revenue Code) as "a political device designed to steer public frustration over taxes towards the IRS and away from Congressional lawmakers." ${ }^{\text {73 }}$ Similarly, here, perhaps the Chief's invocation of IRS Rule signals that regulations promulgated by the IRS do not stand on the same footing as regulations promulgated by any number of other agencies. In other words, whereas traditional agency regulations are owed judicial deference, "IRS Rules" are less deserving of such deference. For the Chief - as for many tax lawyers, judges, and scholars - tax exceptionalism may well still be alive and kicking.

70. This search of the Supreme Court Cases Database on Westlaw was conducted on September 4, 2015. Three additional cases included "IRS rule," but not to refer to a Treasury Regulation. See Bob Jones Univ, v. United States, 461 U.S. 574, 602 n.27 (1983) (quoting congressional statement referring to IRS Revenue Ruling as "IRS rules"); Allen v. Wright, 468 U.S. 737, 742 (1984) (referring to an IRS Revenue Procedure as "IRS rules"), abrogated by Lexmark Int'1, Inc. v. Static Control Components, Inc., 134 S. Ct. 1377 (2014); United States v. Energy Res. Co., 495 U.S. 545, 548 (1990) (referring to IRS Revenue Rulings as "IRS rules").

71. See, e.g., Merits Brief for Petitioners at 6, King v. Burwell, 135 S. Ct. 2480 (2015) (No. 14114) (stating '[ $t]$ hese regulations ('the IRS Rule') contradict the statutory text restricting subsidies to Exchanges "established by the State under section 1311" and then using "IRS Rule" another 36 times throughout the brief).

72. As Ellen Aprill explores in her contribution to this Symposium, the Tax Court in the past similarly had refused to apply Chevron deference to IRS statutory interpretations and may well use King as an excuse to resume that practice. Aprill, supra note 8, at 17 ("Predicting from past case law in this case is much like reading tea leaves; nonetheless, the reluctance of the Tax Court to adopt Chevron and its willingness to cite Brown \& Williamson as a canon of statutory possibility underscores the possibility that the Tax Court will make use of King $v$. Burwell to review and reject tax regulations under a Chevron Step 0.").

73. Andy Grewal, The IRS Code, Yale J. ON REG.: Notice \& Comment (Apr. 14, 2015), http://www.yalejreg.com/blog/the-irs-code-by-andy-grewal. 
If tax exceptionalism is indeed driving the Chief's refusal to accord Chevron deference to the Treasury regulation at issue in King, this new major questions doctrine may well be good for tax only. We do not know yet if the Court (or the lower courts) will extend this sweeping change in administrative law to other regulatory contexts. But we should find out soon enough. The Chief's major questions doctrine is already front and center in a number of legal challenges to agency regulations, including challenges to the agency's interpretation of the contraceptive mandate in the Affordable Care Act and to the Federal Communication Commission's net neutrality regulation. ${ }^{74}$ As one of us has previously noted, legal challenges to the EPA's Clean Power Plan seem like another prime candidate to test the Chief's new doctrine. ${ }^{75}$

It is probably safe to assume that we will soon discover whether the Chief in King v. Burwell intended to cause a sea change in administrative law or was thinking like a tax lawyer and crafting a major questions doctrine that is good for tax only. ${ }^{76}$

\section{CONCLUSION}

So, based on his opinion in King $v$. Burwell, is it fair to wonder whether the Chief Justice is a tax lawyer at heart? As for administrative law, there is some evidence that the Chief is thinking like a tax exceptionalist. Time will tell whether he intended his new major questions doctrine to apply beyond tax. His approach to statutory interpretation, however, even more strikingly reflects how tax law interprets transactions by not letting form (text) trump substance (purpose). Although we doubt the Chief or the Court more generally is actually thinking about tax law's substance-over-form doctrine when engaging in this brand of contextualism, maybe they should be. As this

74. See, e.g., Brief for the Cato Institute as Amicus Curiae in Support of Petitioners at 1, Little Sisters of the Poor Home for the Aged v. Burwell, S. Ct. No. 15-105, 2015 WL 5029190 (Aug. 24, 2015) (arguing that "the threshold question is whether the Departments had the requisite interpretive authority and 'expertise' to resolve this 'major question' of profound social, 'economic and political significance"' (quoting King, 135 S. Ct. at 2489); Amicus Curiae Brief of International Center for Law \& Economics and Administrative Law Scholars in Support of Petitioners at 3-4, U.S. Telecom Ass'n v. FCC, D.C. Cir. No. 15-1063, 2015 WL 4698404 (Aug. 6, 2015) (arguing that "the [net neutrality] Order should be rejected as exceeding the Commission's statutory authority and as presenting and addressing major questions - questions of 'deep economic and political significance,' see, e.g., King v. Burwell ... - that can only be addressed by Congress").

75. See Walker, supra note 39.

76. In her contribution, Kristin Hickman explores a third option-that the majority joined the Chief's opinion to save the regulation yet did not really embrace the Chief's novel major questions doctrines-but Professor Hickman nevertheless argues that there may well be unintended consequences from their joinder. Hickman, supra note 8, at 65-66. As discussed in note 43 supra, Justice Kennedy articulated a similar major questions doctrine at oral arguments, but Professor Hickman is right that we do not know the position of the other joiners (or if Justice Kennedy fully embraces the new doctrine). 
Essay illustrates, there may well be great benefits in looking to tax law (and vice versa) to better understand and further develop other areas of the law such as statutory interpretation and administrative law. ${ }^{77}$

77. For this reason, Andy Grewal's observation on the lack of participation of tax scholars in the King $v$. Burwell litigation is all the more noteworthy. Grewal, supra note 8, at 48. As Professor Grewal notes in his contribution to the Symposium, "Tax professors routinely provide thoughtful analysis of non-core tax provisions, like those relating to the Earned Income Tax Credit. Also, discussions of tax expenditures have enjoyed somewhat of a resurgence in recent years. Interpretive and policy issues related to non-core provisions fit comfortably within the tax professoriate's bailiwick." Id. at 45-46. 